\title{
Research on Identification of Land Damage Types and Analysis of Damage Process in Opencast Coal Mine of Steppe
}

\author{
Yan Jiancheng ${ }^{1,2, *}$, Liu Yong ${ }^{3}$, and Gao Junhai ${ }^{2}$ \\ ${ }^{1}$ Tiandi(Tangshan) Mining Technology Co.Ltd.,Tangshan 063300,China \\ ${ }^{2}$ Tangshan Research Institute,China Coal Technology \& Engineering Group,Tangshan 063012,China \\ ${ }^{3}$ Shenhua Baorixile Energy Corporation,Hulunbuir 021500,China
}

\begin{abstract}
Aiming at the situation of land damage caused by large Opencast Coal Mine in steppe, this paper took Borshil Opencast Coal Mine in Hulunbuir as the research object, identified the types of land damage caused by Opencast Coal Mine in the last 20 years, analysed the space-time sequence and quantity of land damage process, and calculated the coefficient of land damage based on the types of damage. We found that, since 1998 to 2018, the area of land improper excavation and land cover occupation increased year by year in Borshil Opencast Coal Mine, the area of land improper excavation changed inconspicuously between years, and the area of land cover occupation decreased between years; the area of land occupation increased first and then remained unchanged basically, and the proportion decreased from $36.5 \%$ to $16.2 \%$. By 2018 , the total area of land damage in Borshil Opencast Coal Mine was $5150.52 \mathrm{hm}^{2}$, and the ratio of land improper excavation to land cover occupation to land piled up was about 3:5:2. In addition, the land damage coefficient of Borshil Opencast Coal Mine increased first and then decreased, reaching the maximum of $0.6425 \mathrm{hm}^{2} / 10^{4} \mathrm{t}$ in 2011 , and it was $0.196 \mathrm{hm}^{2} / 10^{4} \mathrm{t}$ in $1998-2018$. The data combined with coal mine output can predict the future land damage area of mining area, and provide data support for land reclamation potential survey. It can also provide reference for the implementation of relevant national policies and plans.
\end{abstract}

\section{Introduction}

Most of China's open-pit coal mines are located in the arid and semi-arid ecological fragile areas ${ }^{[1]}$. The mining of open-pit coal mines has completely changed the original land use landscape type ${ }^{[2]}$, seriously damaged the land ${ }^{[3]}$, and the waste dump pressure occupies a large number of land, resulting in a series of problems ${ }^{[4]}$ such as soil quality decline $\mathrm{e}^{[5]}$, ecological environment degradation ${ }^{[6]}$, biodiversity reduction ${ }^{[7]}$. The main types of land damaged by open-pit mining are land excavation, land occupation and land occupation ${ }^{[8]}$. The type of land damage in mining area affects the selection of reclamation direction and measures ${ }^{[9]}$, and the accurate and reasonable determination of the area of land damage in mining area is the key to land reclamation in mining area ${ }^{[10]}$, which is also the basis for land reclamation adaptability evaluation, reclamation engineering design, engineering quantity calculation, capital budget and other work ${ }^{[1]}$.

Taking Shenhua Borshil open pit coal mine as an example, combined with the situation of open pit mining, this paper reveals the types, characteristics and damage process of land damage in different stages of Borshil opencast coal mine, and the research results can provide the basis for the development impact assessment, land reclamation and policy decision-making of similar coal enterprises.

\section{Study Area}

Shenhua Borshil opencast coal mine is located in the central area of Hulunbeir Grassland, one of the four grasslands in the world. Its geographical location is between $119^{\circ} 53^{\prime} 37 " \sim 119^{\circ} 58^{\prime} 07^{\prime \prime} \mathrm{E}, 49^{\circ} 18^{\prime} 45^{\prime \prime}$ $49^{\circ} 29^{\prime} 30^{\prime \prime} \mathrm{N}$, with an elevation of $601.88 \sim 724.90 \mathrm{~m}$. it is administratively subordinate to Chenbalu Banner of Hulunbeir City ${ }^{[12]}$. The project was started in September 1998 and completed in April 2001 with a design production capacity of $1.8 \mathrm{Mt} / \mathrm{a}$. In $2009,10.0 \mathrm{Mt} / \mathrm{a}$ technical transformation was completed, and the capacity reached 30.0Mt in 2012.

The landform of the mining area is a slightly undulating high plain, which is high in the northeast and low in the southwest. The climate belongs to the mid temperate semi-arid continental climate with an annual average precipitation of $350 \mathrm{~mm}$, mostly concentrated from July to September with a large variability. The zonal vegetation type is Leymus chinensis community in meadow grassland area, and the zonal soil type is dark chestnut soil.

\section{Data Sources and Analysis Methods}

\footnotetext{
${ }^{*}$ Corresponding author: jc_yan@163.com
} 


\subsection{Data sources}

All data in this paper are from Shenhua Borshil Energy Co., Ltd., including the plan of mining engineering, annual output, topographic map of mining area, design specification of coal mine and other production technical data from 2009 to 2018.

The topographic map at the end of each year of the mining area is integrated on the initial topographic map of the mining area to identify the type of land damage.

\subsection{Analysis methods}

\subsubsection{Types of land damage}

The land damage of production and construction projects can be divided into direct damage and indirect damage. The direct damage mainly includes excavation damage, subsidence, occupation and occupation. For open-pit mining, the main types are excavation damage, occupation and occupation ${ }^{[13]}$.

Excavation destruction refers to the direct destruction of the original surface morphology and biological population caused by the production and construction activities. The original ecosystem no longer exists, and the most direct damage to the land.

Coverage refers to the production and construction activities due to the excavation of waste rock and soil piles in the original landform, the loss of the original ecosystem, the formation of artificial landforms and artificial plant communities.

Occupation refers to the production and construction activities that change the original land use type into industrial site and transportation land, and still play the use value of land.

\subsubsection{Coefficient of land damage}

The land damage coefficient refers to the area of land damage caused by every ten thousand tons of coal mining in a period of time [14], mainly from the land damage coefficient based on the landform type and the land damage coefficient based on the damage type [15], this study adopts the land damage coefficient based on the damage type. The coefficient of land damage can be used to study the stage and dynamic of land damage in a single mining area, and can also be used to calculate the area of land damage on the policy scale. From the perspective of land damage caused by coal mining, the land damage coefficient is closely related to the geomorphic type, mining technology and the type of damaged land.

\section{RESULTS AND ANALYSES}

\subsection{Analysis on the change of land damage types in different stages}

In the early stage of mining (1998-2009), Borshil opencast coal mine is in the construction period and the initial stage of production. It is mainly engaged in the construction of maintenance department, coal preparation plant, coal storage, sewage treatment plant, water supply station, automatic coal loading station, comprehensive office building and other main works, with low production capacity. Due to the occupation of land by infrastructure and the large area of land occupied by offsite discharge pressure, the two areas are $554.08 \mathrm{hm}^{2}$; The total area of excavation damage is $23.71 \mathrm{hm}^{2}$, accounting for $4.1 \%$ of the total land damage area.

During the stable production period of the mine (20092018 ), the production capacity of the mine is $30.0 \mathrm{mt} / \mathrm{a}$. The construction of mine infrastructure and supporting facilities has been completed, the rate of rock and soil stripping and the rate of land excavation loss have gradually increased, and the area of excavation loss has increased year by year. Because of the gradual start of internal dumping, the area of land pressure decreased year by year. However, the land occupied area is basically unchanged, and the proportion of the total land damaged area has also declined, from $36.5 \%$ in the initial stage of mining to $16.2 \%$.

From the perspective of inter annual changes, there is no obvious inter annual change in the area of land excavation loss in 2011-2013, 2013-2016 and 2016-2018; the land occupation area is decreasing year by year, and there is no regular change in the area of land occupation. In 2013-2016, the land occupation was negative, which was caused by the reduction of temporary site occupation by mining enterprises.

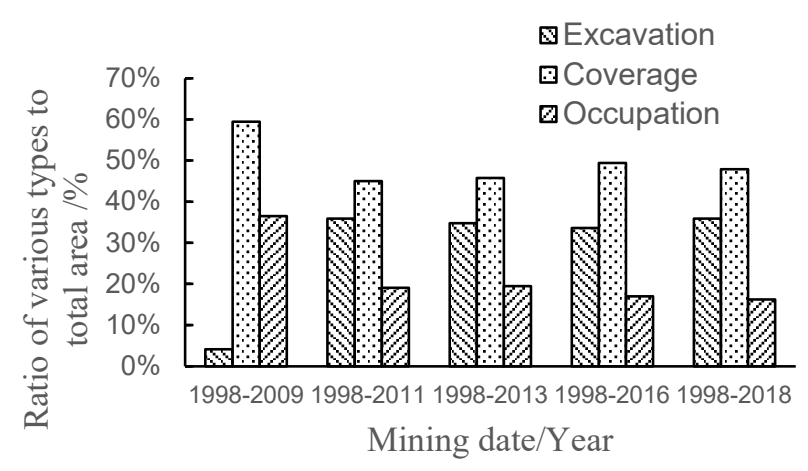

Fig.1 Change of Land Damage Types in Different Mining Time

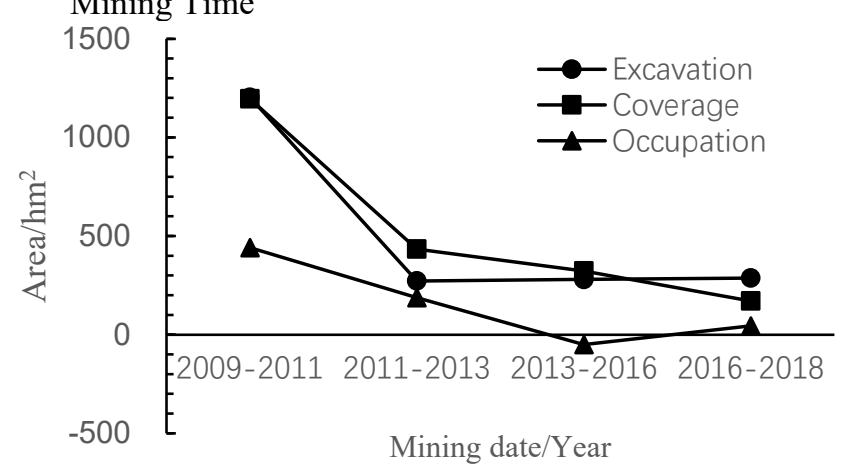

Fig.2 Interannual Variation of Different Land Damage Types 


\subsection{Analysis on the change of land damage coefficient in different stages}

It can be seen from the figure that with the increase of coal mine output, the land damage coefficient of Borshil opencast coal mine experienced the process of increasing first and then decreasing, reaching the maximum of $0.6425 \mathrm{hm} 2 / 10000 \mathrm{t}$ in 2011. During 2009-2011, due to the completion of the first mining area and the formal mining of the second mining area, the surface excavation and the dumping of the Quaternary loose layer led to the increase of the damaged area of the land, and the production capacity of the mine did not reach the limit, resulting in the increase of the damage coefficient.

During 1998-2018, the land damage coefficient of Borshil opencast coal mine was $0.196 \mathrm{hm}^{2} / 10^{4} \mathrm{t}$, which was lower than that of Shanxi Province, Inner Mongolia Autonomous Region and the whole country, and higher than that of Antaibao opencast coal mine ${ }^{[16]}$ (2001-2009), which was $156 \mathrm{hm}^{2} / 10^{4} \mathrm{t}$.

Table 1 Land Damage Coefficient Table for Open Cast Coal Mining

\begin{tabular}{cccc}
\hline Mine $/$ & Year & $\begin{array}{c}\text { Land Damage } \\
\text { Coefficient } \\
\left(\mathrm{hm}^{2} / 10^{4} \mathrm{t}\right)\end{array}$ & Data sources \\
\hline Province & & 0.196 & this paper \\
Antaibao & $2001-2009$ & 0.156 & References 16 \\
Shanxi & $2000-2010$ & 0.243 & References 15 \\
Inner & Not mentioned & 0.24 & References 10 \\
Mongolia & $1998-2018$ & 0.211 & References 14 \\
China & $1995-2010$ & 0.24 &
\end{tabular}

\section{DISCUSSION}

Accurate identification of the temporal and spatial order, quantity, type and degree of land damage types in mining areas can provide data support for ecological restoration and sustainable development of mining areas ${ }^{[17]}$. In Borshil opencast coal mine, land pressure occupies the largest area, accounting for about $50 \%$ of the total damaged land area in all stages of the coal mine production cycle. The waste dump is also the key to the reclamation of mining area. The reclamation of waste dump is not only afforestation or simple restoration of cultivated land. More and more attention has been paid to the landscape reconstruction of waste dump [18] [19]. Geomorphic reconstruction is the foundation and guarantee of the quality of reclaimed land in mining area [20]. According to the characteristics of the terrain and landform of the mine, the mining design, mining technology and land damage type are studied. Through orderly dumping and land shaping, a new landform coordinated with the surrounding landscape is reshaped, which can preferentially inhibit the water and soil loss and improve the reclamation efficiency ${ }^{[21]}$. It can be seen from the paper that in 2016, the land occupation area of Borshil opencast coal mine has increased significantly, which is caused by the implementation of landform reconstruction by mining enterprises and slope cutting of waste dump.

The land damage coefficient is put forward under the background of the national land reclamation potential investigation and research work. For a single mining area, the land damage coefficient of a certain stage is determined, which can predict the future land damage area in combination with the coal mine output, and provide accurate data support for the coal mine reclamation; for the whole province and even the whole country, the land damage coefficient can reasonably calculate the area. The area of damaged land can save the manpower and material resources of detailed investigation of damaged land and provide reference for the implementation of relevant national policies and plans.

\section{CONCLUSION}

1) The main types of land damage in Borshil opencast coal mine are land excavation, land occupation and land occupation. From 1998 to 2018, the total area of land damage in Borshil opencast coal mine was $5150.52 \mathrm{hm}^{2}$, with a ratio of 3:5:2.

2) From 1998 to 2018, the land damage coefficient of Borshil opencast coal mine was $0.196 \mathrm{hm}^{2} / 10^{4} \mathrm{t}$.

\section{Acknowledgements}

The research was supported by Special Youth Project of Science and Technology Innovation and Entrepreneurship Fund of Tiandi Science and Technology Co., Ltd(Grant No.2018-TD-QN041) and National Key R\&D Program of China (Grant No.2016YFC0501105).

\section{REFERENCES}

1. Zh. Bai, J.Zhao, J. Li, et al. Ecosystem Damage in a Large Opencast Coal Mine - a Case Study on Pingshuo Surface Coal Mine,China.Acta Ecologica Sinica, 19, 6 (1999).

2. L. Zhang, S. Zhang, H. Ye ,et al. Landscape Indices of Land Damage and Land Reclamation in an Opencast Coal Mine. Resources Science, 36, 1 (2014).

3. Y. Cao, Zh. Bai . Analysis of Change and Driving Force of Land Utilization in Antaibao Open-castmine. Resources Industries. 8 , 4 (2006).

4. L. Guo, J. Wang, Zh. Bai, et al. Analysis of Spatial Variability of Soil Granules in Early Stage of Reclamation at Opencast Coal Mine Dump in Loess Area. China Mining Magazine, 24, 2 (2015).

5. D. Xia, F. Li , X.Yuan, et al. Research Situation of Ecological Rehabilitation Technology in Rock Openpit Mine and Its Developing Trend. Metal Mine, 499 (2018).

6. Y. Yuan, Zh. Zhao, Zh. Bai, ,et al. Technology System and Method of Biodiversity Restoration for the Reclamation of Opencast Coal Mine: a Case Study from the Dumps in Pingshuo Mine. China 
Mining Magazine, 26, 8 (2017).

7. Y. Rong, Zh. Hu, Y. Fu, et al. Comparative Study on Land Reclamation Technology in Typical Surface Coal Mine in Steppe Region Between China and USA. China Mining Magazine, 26 , 1 (2017).

8. Q. Sun, Zh. Bai , Y. Cao, et al. Ecological Risk Assessment of Land Destruction in Large Open-pit Mine.Transactions of the Chinese Society of Agricultural Engineering, 31, 17 (2015).

9. Zh. Yang, Zh. Bai, Q. Zhang, et a1. Study on Land Use/Cover Change During the Process of Ecosystem Damaging in Mine Area-Taking Pingshuo Anjialing Mine as an Example.Journal of Shanxi Agricultural University, 23, 4 (2013).

10. Ch. Liu, Zh. Bai, J. Zhou, et al. Application of Typical Sample Analysis in Large-scale Survey of Damage Land. Journal of Shanxi Agricultural University(Natural Science Edition), 31, 2(2011).

11. H. Zhang, Sh. Wang, Ch. Li. Research on Land Destruction Prediction Methods of Land Reclamation in Coal Mining Area. Metal Mine, 447(2013).

12. Wurenqiqige, D. Zhang, T. Lei, et al. The Effects of Coal Mining Subsidence on Grassland Plant Communities: Take Borxil Coal Mine As an Example. Journal of Arid Land Resources and Environment, 30, 12 (2016).

13. The ministry of land and resources land management center. Practice of Land Reclamation Programming (Volume 2). Beijing: China land press, (2011).

14. He Shujin,Su Guangquan. Utilization of Waste Land in Mining Areas of China. Resources Science, 24, 2 (2002).

15. Y. Cao, Zh.Bai, W. Zhou,et al Impact Factors of Coal Mining Land Damage at Different Scales in Shanxi Province . China Mining Magazine. 23, 8 (2014).

16. L. Guo. Study on Reclamation Potential of Destruction Land of Coal and Metal Mine in China . China University of Geosciences(Beijing),2011.

17. Y. Zhou, W. Zhou, Zh. Bai. The Damaged Lands and Their Reclamation Potential in Mining Districts. Resources Industries, 15, 5 (2013).

18. C. Yang, T. Zhao, B. Xie, et al. Simulation of Topographic Reconstruction of Abandoned Mine Based on Sub-watershed Natural Geomorphology. Transactions of the Chinese Society of Agricultural Engineering, 30, 1 (2014).

19. Y. Wang, Zh. Wei. Landscape Terrain Restoration of Land Reclamation in Open-pit Mining. Metal Mine, 435(2012).

20. Zh. Bai, W. Zhou, J. Wang, et al. Rethink on Ecosystem Restoration and Rehabilitation of Mining Areas. China Land Science, 32, 11(2018).

21. L. Zhang, J. Wang, T. Liu. Landscape Reconstruction and Recreation of Damaged Land in Opencast Coal Mine: a Review. Advances in Earth Science, 31, 12(2016). 